\title{
Aplikasi Filter Pasif Rc Untuk Mereduksi Harmonik Pada Ac/Dc/Ac Konverter
}

\author{
Asnil*) \\ *Staf Pengajar Jurusan Teknik Elektro, FT-UNP
}

\begin{abstract}
This paper presents the design and analysis of a low pass passive filter to reduce harmonics component at the ac side (input) of three-phase ac/dc/ac converter. The filter configuration consists of resistor and capasitor, that cut off the frequency above $150 \mathrm{~Hz}$.
\end{abstract}

Keyword: voltage, current, harmonic distortion.

\section{Pendahuluan}

Penggunaan ac/dc/ac konverter tiga fasa pada industri mempunyai peranan penting terutama untuk mengatur kecepatan motor induksi tiga fasa. Namun demikian, penggunaan konverter ini menimbulkan efek lain pada sistem yang disebut dengan harmonik. Konverter dikategorikan kepada beban non linear yang merupakan penyebab timbulnya harmonik. Apabila harmonik ini tidak dikendalikan, akan membawa dampak yang tidak baik kepada sistem, karena harmonik yang dihasilkan oleh konverter akan mengalir ke sumber dan ke beban dari konverter itu sendiri.

Pada penelitian ini, solusi yang ditawarkan untuk mereduksi harmonik adalah dengan pemasangan filter pasif jenis low pass dengan komponen resistor dan kapasitor. Filter ini dipasang pada sisi input (sisi ac) dari konverter dengan menggunakan power system analizer untuk mengetahui kandungan harmonik pada sistem. Pengukuran dilakukan pada dua skenario, yakni pada saat konverter tidak dipasang filter dan setelah konverter dipasang filter.

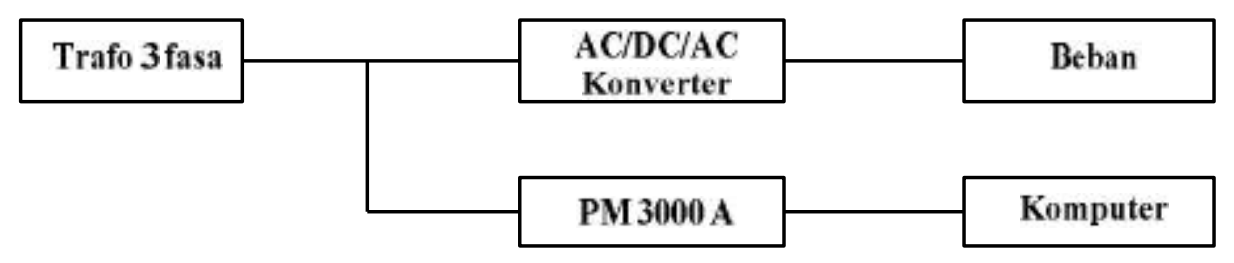

Gambar 1. Blok diagram penelitian sebelum dipasang filter pasif

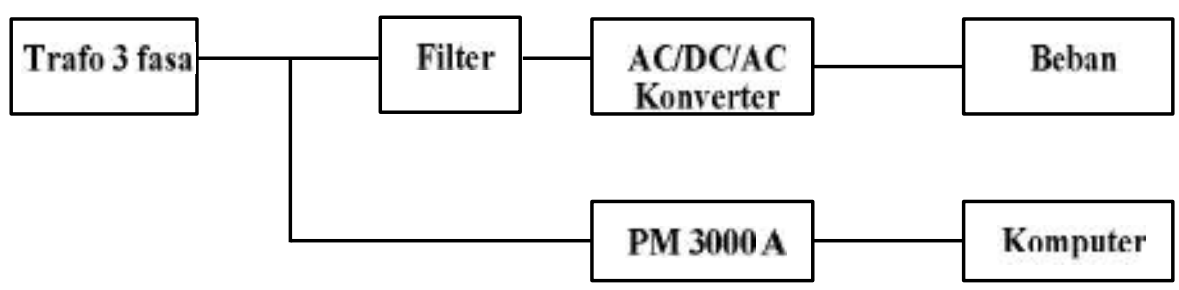

Gambar 2. Blok diagram penelitian setelah di pasang filter pasif

\section{Tinjauan Pustaka \\ 2.1. Harmonik}

Harmonik merupakan salah satu komponen sinusoida dari satu periode gelombang yang mempunyai frekuensi kelipatan bulat dari frekuensi fundamentalnya. Gelombang yang terdistorsi terdiri dari beberapa harmonik, dan harmonik yang pertama dikenal sebagai frekuensi dasar atau fundamental. 
Seterusnya harmonik dengan kelipatan ganjil dari frekuensi fundamental disebut dengan harmonik ganjil dan harmonik kelipatan genap dari frekuensi fundamental disebut sebagi harmonik genap.

Distorsi harmonik disebabkan karena adanya beban non linear dalam sistem tenaga (Dugan, 2004). Beban non linear adalah salah satu jenis peralatan listrik yang berperilaku dapat mengubah bentuk gelombang arus atau tegangan kepada bentuk tertentu yang tidak sinusoida lagi, dan salah satu contohnya adalah ac/dc/ac konvereter. Gambar berikut menunjukan bentuk gelombang sinusoida yang terdistorsi oleh harmonik.

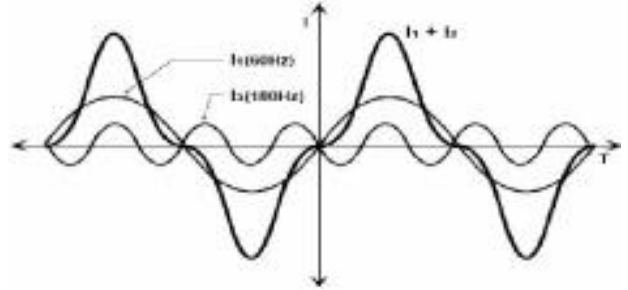

Gambar 3. Gelombang fundamental dan harmonik ke-3 berbeda fasa $180_{0}$

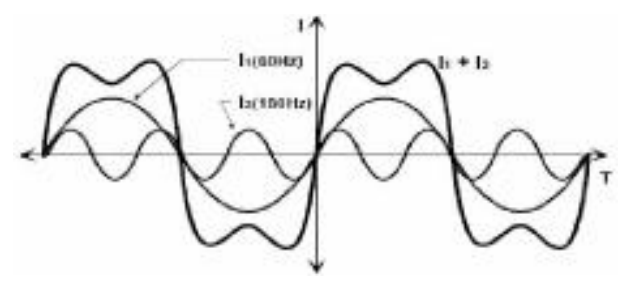

Gambar 4. Gelombang fundamental dan harmonik ke- 3 berbeda fasa $0_{0}$

Harmonik ke-3 artinya harmonik yang mempunyai frekuensi tiga kali dari frekuensi fundamentalnya, jadi bila frekuensi fundamental $50 \mathrm{~Hz}$, maka harmonik ke-3 mempunyai frekuensi 150 $\mathrm{Hz}$, atau dapat dituliskan dengan persamaan $\mathrm{f} \mathrm{n}=\mathrm{n} \mathrm{x}$, dimana $\mathrm{n}$ bilangan bulat. Karaktersitik harmonik dapat direpresentasikan dengan deret fourier.

$f(t)=\frac{a_{0}}{2}+\sum_{n=1}^{m}\left\{a_{n} \cdot \cos \left(n \omega_{0} t\right)+b_{n} \cdot \sin \left(n \omega_{0} t\right)\right\}$

Atau dalam bentuk lain menjadi,

$f(t)=C_{0}+\sum_{n=1}^{\infty} C_{n}, \sin \left(n \omega_{0} t+\varphi_{n}\right)$
Dimana $C_{0}=\frac{\widehat{C}_{0}}{2} \quad=$ komponen

dc

$$
C_{n}=\sqrt{a_{n}^{2}+b_{n}^{2}} \quad=\text { nilai }
$$

harmonik yang ke-n

$$
\varphi=\tan ^{-1}\left(\frac{a_{n}}{\hbar_{n}}\right) \quad=\text { sudut fase }
$$

harmonik ke-n

Deret fourier dapat diaplikasikan untuk persamaan tegangan dan arus harmonik sebagai berikut:

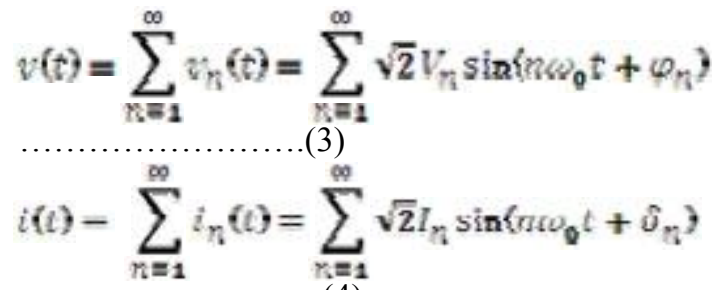

dengan bagian dc biasanya diabaikan untuk kesederhanaan, $V_{n}$ dan $I_{n}$ adalah nilai harmonik untuk orde ke-n pada masing-masing tegangan dan arus.

Perbandingan nilai rms komponen harmonik terhadap komponen dasar biasanya dinyatakan dalam bentuk persen. Indeks ini disebut dengan THD (Total Harmonic Distortion), dan biasanya digunakan untuk menyatakan penyimpangan bentuk gelombang yang mengandung harmonik terhadap gelombang sinus yang sempurna dalam satu periode. Dimana nilai THD dari bentuk gelombang sinus sempurna pada frekuensi dasar adalah nol.

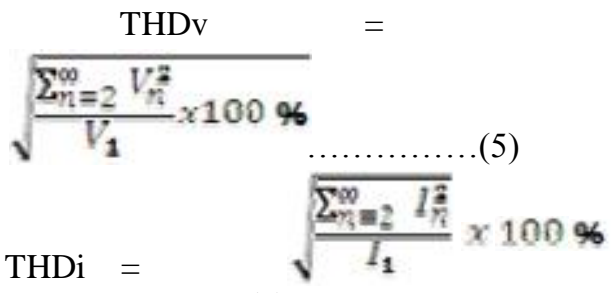
(6)

Persamaan (5) dan (6) merupakan persamaan untuk nilai THD tegangan dan THD arus. Kontribusi masing-masing komponen harmonik terhadap distorsi arus dinyatakan oleh IHD (Individual Harmonik Distortion). Nilai IHD harmonik tegangan dan arus pada harmonik ke-n didefinisikan sebagai $\frac{V_{n}}{V_{1}}$ 
dan $\frac{I_{\mathfrak{n}}}{I_{1}}$. Batas-batas nilai harmonik

berdasarkan standar IEEE 519-1992. tegangan dan arus di sesuaikan

Tabel 1. Batas distorsi tegangan menurut standar IEEE 519-1992

\begin{tabular}{|c|c|c|}
\hline Bus voltage at PCC & $\begin{array}{c}\text { Individual voltage } \\
\text { distortion }(\%)\end{array}$ & $\begin{array}{c}\text { Total voltage distortion } \\
\text { THD }(\%)\end{array}$ \\
\hline $69 \mathrm{kV}$ and below & 3.0 & 5.0 \\
\hline $69.001 \mathrm{kV}$ through $161 \mathrm{kV}$ & 1.5 & 2.5 \\
\hline $161.001 \mathrm{kV}$ and above & 1.0 & 1.5 \\
\hline
\end{tabular}

Tabel 2. Batas distorsi arus menurut standar IEEE 519-1992

\begin{tabular}{|c|c|c|c|c|c|c|}
\hline Isc/IL & $<11$ & $11 \mathrm{~h}<17$ & $17 \mathrm{~h}<23$ & $23 \mathrm{~h}<35$ & $h$ & TDD \\
\hline$<20$ & 4.0 & 2.0 & 1.5 & 0.6 & 0.3 & 5.0 \\
\hline $20<50$ & 7.0 & 3.5 & 2.5 & 1.0 & 0.5 & 8.0 \\
\hline $50<100$ & 10.0 & 4.5 & 4.0 & 1.5 & 0.7 & 12.0 \\
\hline $100<1000$ & 12.0 & 5.5 & 5.0 & 2.0 & 1.0 & 15.0 \\
\hline$>1000$ & 15.0 & 7.0 & 6.0 & 2.5 & 1.4 & 20.0 \\
\hline
\end{tabular}

\subsection{Low pass filter}

Low-pass filter yang digunakan dalam penelitian ini terdiri dari gabungan komponen resistor dan kapasitor yang dipasang pada sisi input konverter. Filter ini dirancang untuk dapat melewatkan frekuensi di bawah frekuensi cut-off dan menahan atau meredam frekuensi di atas frekuensi cut-off. Gambar berikut memperlihatkan tipe filter pasif jenis lowpass yang digunakan pada penelitian.

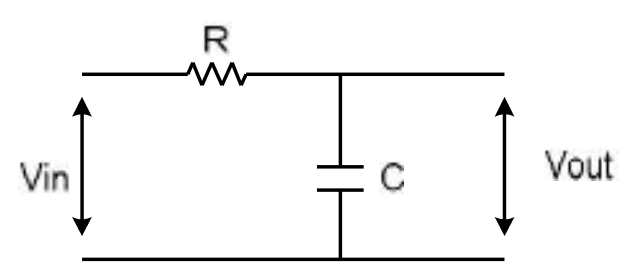

Gambar 5. Rangkaian filter pasif jenis low-pass

Vin adalah tegangan input yang masuk ke rangkaian dan Vout adalah tegangan yang keluar dari rangkaian yang menjadi input untuk konverter. Nilai Vout dapat dicari dengan persamaan berikut;

$$
V_{\text {gut }}(s)=V_{i n}(s) \frac{1 / C_{s}}{R+1 / C_{s}}=V_{i n}(s) \frac{1}{1+R C_{5}}
$$

Nilai resistor dan kapasitor dapat ditentukan dengan terlebih dahulu menentukan nilai frekuensi cut-off, yaitu untuk menentukan pada frekuensi berapa sinyal dapat dilewatkan. Menentukan nilai resistor dan kapasitor dapat digunakan persamaan berikut;

$$
f_{0}=\frac{1}{2 \pi R C}
$$

Dimana, fo adalah frekuensi cut-off. Setelah menetukan nilai frekuensi cut-off dan nilai dari kapasitor, maka nilai resistor dapat dicari. Apabila nilai frekuensi cut-off dan nilai resistor yang ditentukan terlebih dahulu, nilai kapasitor juga dapat dicari dengan menggunakan persamaan (2.22). Menentukan sudut fasa dari frekuensi cut-off dapat digunakan persamaan berikut;

$\varphi=-\operatorname{arctaa}(2 \pi f R C)$

dengan tatapan waktu

$\tau=R C$ 
Secara teori, nilai frekuensi yang berada di atas cut-off akan dilewatkan melalui kapasitor, dan yang berada di bawah frekuensi cut-off akan tetap dialirkan menuju beban. Hal ini bisa terjadi karena nilai reaktansi dari kapasitor akan semakin kecil jika nilai frekuensi semakin besar sehingga mudah untuk dilewati. Begitu juga sebaliknya dengan reaktansi jaringanya, akan semakin besar jika nilai frekuensi bertambah sehingga semakin sulit untuk dilewati oleh frekuensi harmonik tinggi.

\section{Hasil dan Pembahasan}

Sumber tegangan yang dipakai dalam penelitian ini adalah trafo 3 fasa yang disuplay dari jaringan PLN. Sedangkan konverter yang dipakai adalah AC/DC/AC konverter tiga fasa dengan kemampuan 0,75 KW, 380/220 Volt. Konverter di gunakan untuk kendali kecepatan motor induksi tiga fasa 0,37 $\mathrm{KW}, 50 \mathrm{~Hz}$

III.1. Hasil pengukuran nilai harmonik pada saat konverter belum dipasang filter.

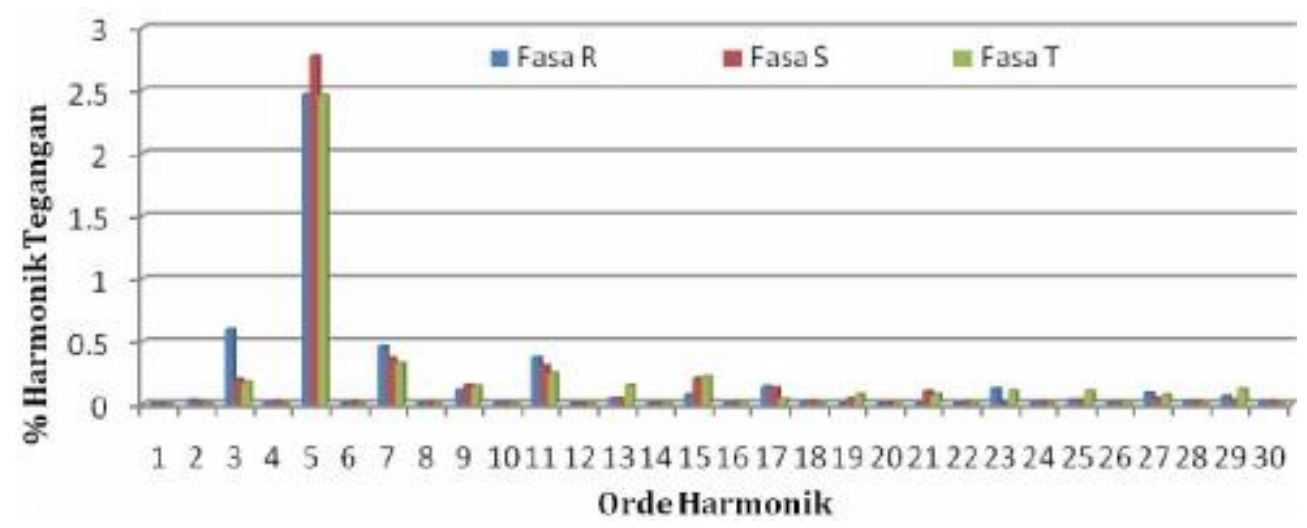

Gambar 6. Spektrum tegangan harmonik sebelum dipasang filter

Dari gambar di atas, terlihat bahwa komponen harmonik didominasi oleh harmonik orde ganjil dengan nilai komponen tertinggi pada orde ke-5 fasa $\mathrm{S}$ dengan nilai $2,772 \%$, sedangkan fasa $\mathrm{R}$ dan $\mathrm{T}$ adalah $2,465 \%$ dan $2,461 \%$.
Sedangkan untuk nilai total distorsi harmonik (THD) tegangan masingmasing untuk fasa $\mathrm{R}, \mathrm{S}$, dan T adalah $2,615 \%, 2,839 \%$, dan $2,535 \%$.

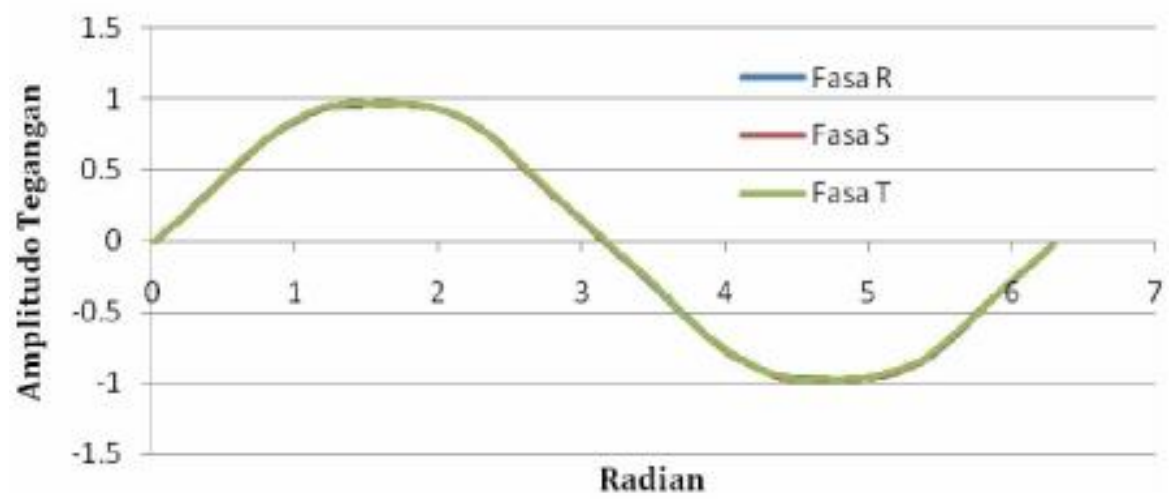

Gambar 7. Bentuk gelombang tegangan sebelum dipasang filter 


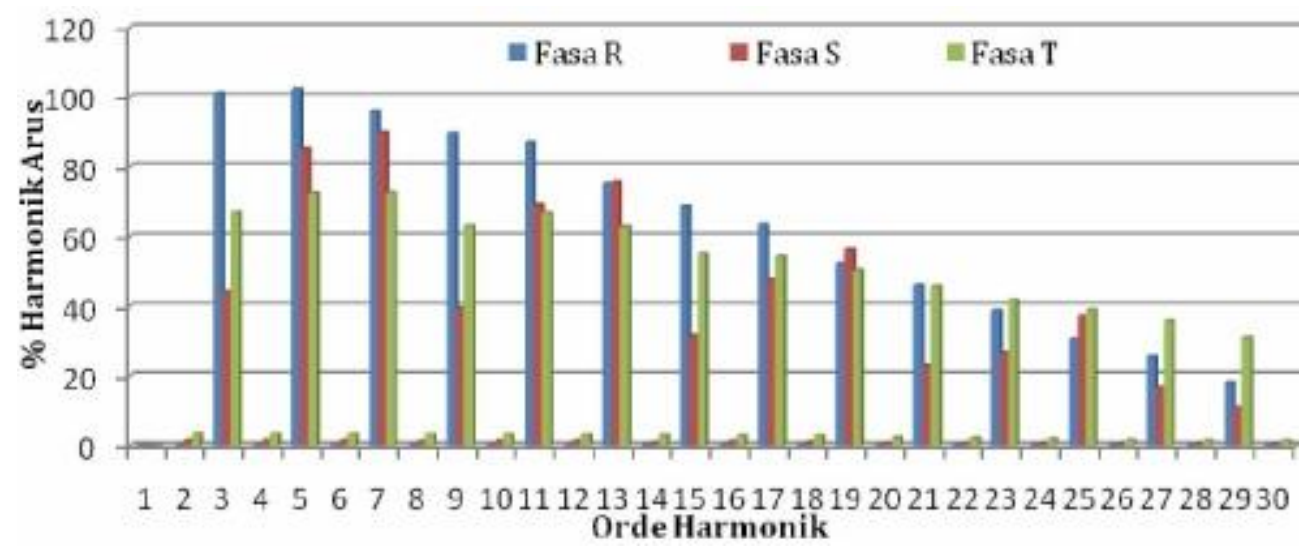

Gambar 8. Spektrum arus harmonik sebelum dipasang filter

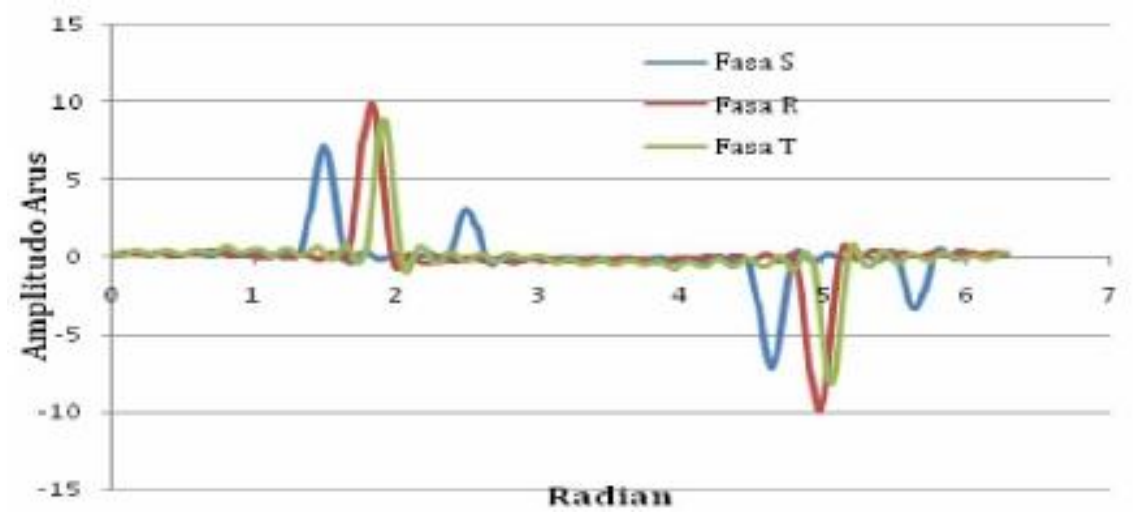

Gambar 9. Gelombang arus harmonik sebelum di pasang filter

Dari gambar 8 dan gambar 9 di atas, dapat dilihat arus harmonik tertinggi terdapat pada orde ke-5, yaitu fasa $\mathrm{R}$ dengan nilai $102,3 \%$, diikuti fasa $\mathrm{S}$ sebesar $89,94 \%$, dan fasa T sebesar $72,67 \%$. Sedangkan nilai Total distorsi harmonik (THD) arus pada fasa $\mathrm{R}$ adalah sebesar $261,319 \%$, pada fasa S sebesar $197,376 \%$, dan pada fasa $\mathrm{T}$ sebesar $208,965 \%$.

Dari hasil penelitian yang dilakukan, didapatkan nilai komponen arus harmonik melebihi batas yang ditentukan seperti yang tertera pada standar IEEE 519-1992. Sedangkan nilai komponen harmonik untuk tegangan masih pada batas yang diizinkan.

\section{III.2. Filter Pasif}

Berdasarkan hasil penelitian seperti yang telah diperlihatkan sebelumnya, didesainlah sebuah low pass filter yang terdiri dari komponen resistor dan kapasitor. Filter ini diharapkan dapat melewatkan frekuensi yang berada di bawah frekuensi cut-off dan memotong atau mengurangi amplitudo di atas frekuensi cut-off, dimana frekuensi cut-off adalah $150 \mathrm{~Hz}$. Setelah menentukan frekuensi cut-off, maka ditentukan pula nilai kapasitor yang akan digunakan, hal ini dilakukan karena nilai kapasitor yang tersedia di pasaran sangat terbatas. Untuk mencari nilai resistor digunakan persamaan (8). Dari hasil perhitungan dengan frekuensi cut-off $150 \mathrm{~Hz}$ dan kapasitor yang digunakan adalah 120

$\mu F$, maka di dapat nilai resistor sebesar 8,85 Ohm. Resistor dengan nilai 8,85 Ohm tersebut tidak ada tersedia di pasaran, selain dari itu, resistor yang digunakan harus memiliki kemampuan daya yang cukup besar.

Upaya yang dilakukan mengatasi hal ini adalah dengan membuat lilitan menggunakan kawat nikelin hingga 
diperoleh nilai resistansi mendekati hasil rancangan. Nilai resistan yang digunakan adalah $9 \mathrm{Ohm}$, hal ini dikarenakan sulitnya untuk mendapatkan nialai resistansi sebesar 8,85 Ohm. Berdasarkan nilai resistansi dan kapasitansi yang diperoleh, maka nilai frekuensi cut-off berubah menjadi $147,44 \mathrm{~Hz}$ (menggunakan persamaan 8).

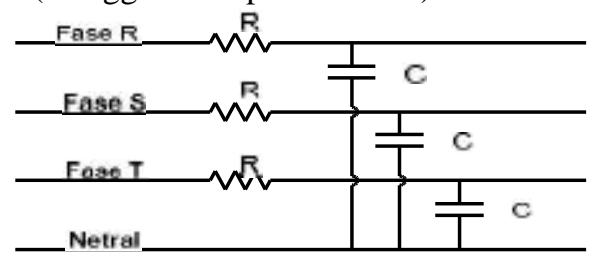

Gambar 10. Rangkaian filter yang digunakan pada penelitian
Berdasarkan hasil rancangan filter yang digunakan pada penelitian, maka amplitudi gelombang yang mempunyai frekuensi di bawah 147,44 Hz akan dilewatkan dan frekuensi di atas 147, 44 $\mathrm{Hz}$ akan mengalami peredaman.

Tahapan selanjutnya adalah memasang filter pada ragkaian penelitian seperti pada gambar 2, kemudian melakukan penelitian selanjutnya untuk melihat seberapa besar pengaruh filter pasif yang dibuat dalam meredam arus harmonik.

III.3. Hasil pengukuran nilai harmonik setelah dipasang filter

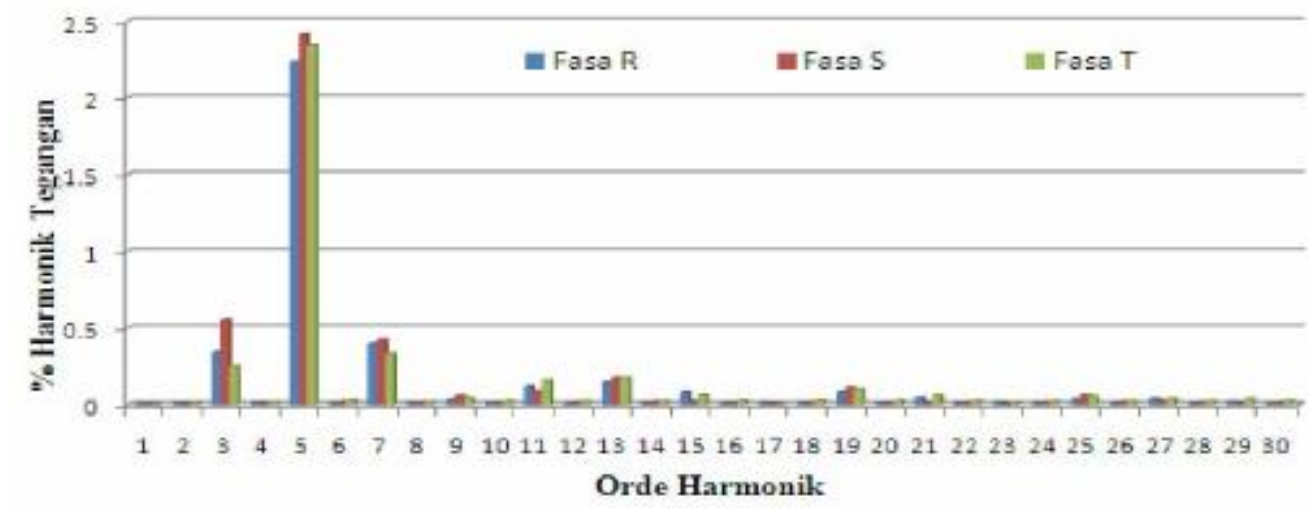

Gambar 11. Spektrum harmonik tegangan setelah dipasang filter

Setelah pemasangan filter, orde harmonik tetap didominasi oleh orde ganjil, yakni orde ke-5. Berturut-turut fasa R, fasa S dan fasa T sebesar 2,40\%, $2.419 \%$, dan $2,345 \%$. Dengan demikian terjadi penurunan tegangan sebesar $0,225 \%$ pada fasa $R, 0,353 \%$ pada fasa $S$, dan $0.116 \%$ pada fasa T. Sedangkan nilai THD tegangan berturut-turut fasa $\mathrm{R}, \mathrm{S}$, dan $\mathrm{T}$ adalah $2,314 \%, 2,529 \%$, dan $2,402 \%$. Dengan demikian terjadi penurunan nilai THD tegangan sebesar $0,307 \%$ pada fasa $\mathrm{R}, 0,311 \%$ pada fasa $\mathrm{S}$, dan $0,312 \%$.

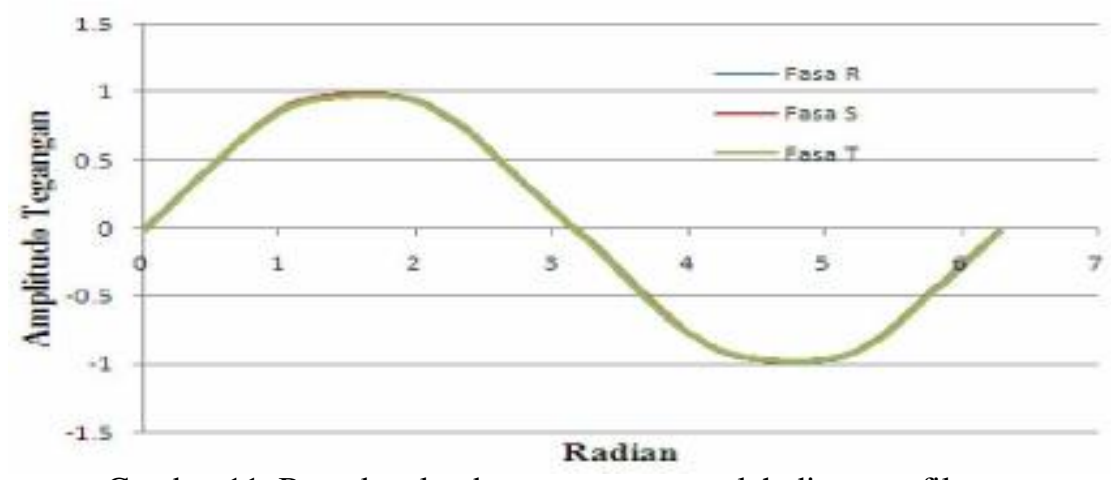

Gambar 11. Bentuk gelombang tegangan setelah dipasang filter 


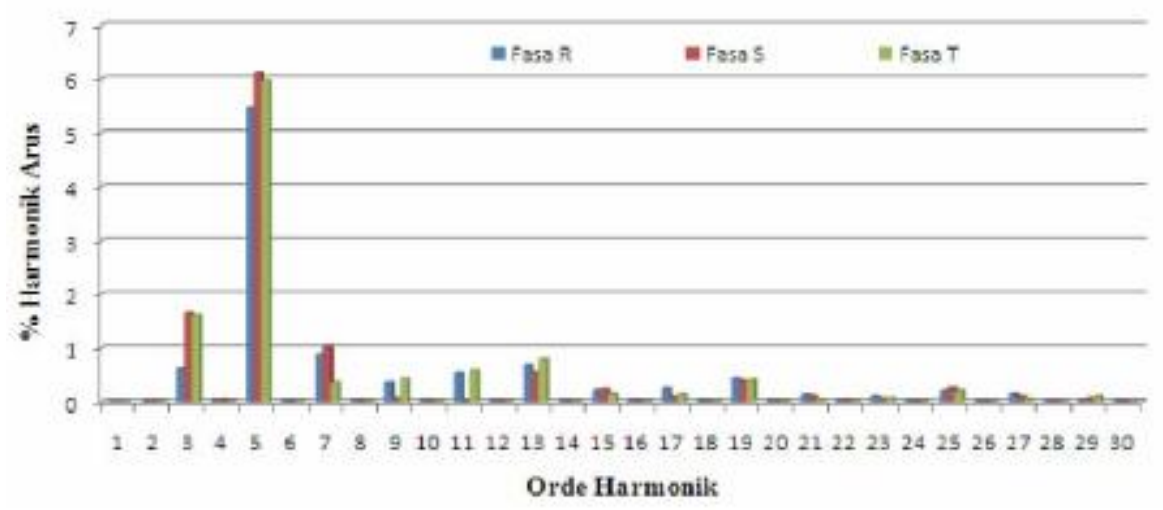

Gambar 12. Spektrum harmonik arus setelah dipasang filter

Setelah dipasang filter, terjadi penurunan harmonik arus yang besar. Setelah dipasang filte, $r$ harmonik arus untuk fasa $\mathrm{R}, \mathrm{S}$, dan $\mathrm{T}$ berturut-turut sebesar 5,622\%, 6,445\%, dan 6,295\%. Dengan demikian, terjadi penurunan harmonik sebesar $96,84 \%$ untuk fasa $\mathrm{R}$, $79,08 \%$ untuk fasa $S$, dan $66,52 \%$ untuk fasa T. Sedangkan nilai THD arus setelah dipasang filter menjadi $5,679 \%$ fasa $\mathrm{R}$, $6,471 \%$ fasa $\mathrm{S}$, dan $6,307 \%$ fasa $\mathrm{T}$. Dengan demikian terjadi penurunan THD arus setelah dipasang filter sebesar $255,64 \%$ pada fasa $R, 190,905 \%$ fasa $S$, dan 202,658 pada fasa $\mathrm{T}$.

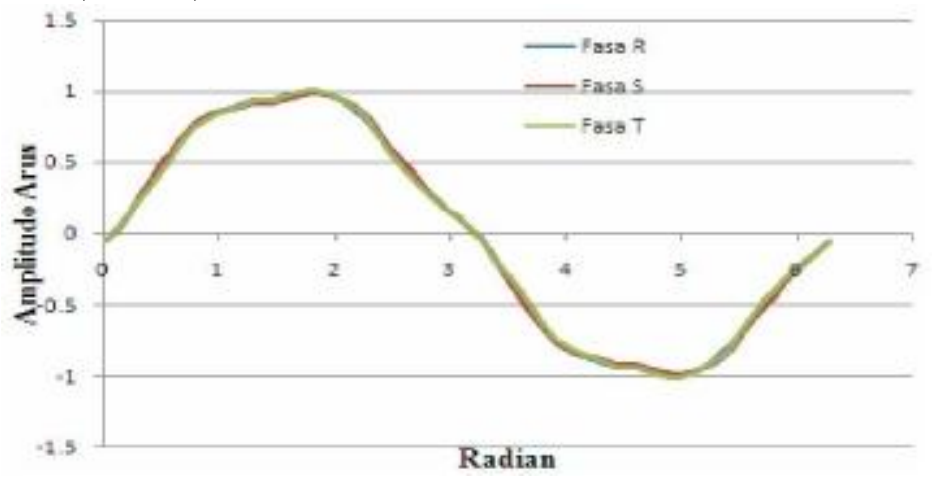

Gambar 13. Gelombang arus harmonik setelah dipasang filter

Dari hasil penelitian yang dilakukan, dapat dilihat terjadi penurunan nilai harmonik yang besar, dimana filter yang digunakan adalah jenis low pass dengan komponen resistor dan kapasitor.

\section{KESIMPULAN}

Dari hasil penelitian yang dilakukan dapat dilihat bahwa untuk mereduksi nilai harmonik dapat dilakukan menggunakan filter. Pada penelitian ini digunakan filter pasif jenis low pass dengan komponen resistor dan kapasitor. Filter yang digunakan dapat mereduksi nilai orde harmonik tegangan sampai $0,353 \%$, THD tegangan sampai $0,312 \%$.

Sedangkan untuk orde harmonik arus filter bisa mereduksi sapai 96,84\% dan THD arus bisa direduksi sampai $255,64 \%$.

\section{REFERENSI}

Ali Emadi, Abdolhosein Nasiri, Stoyan B. Bekiarou., 2005, "Uninterruptible 
Power Supplies and Active Filters “, CRC Press, New York.

Arillaga, Jos dan Neville R. Watson., 2003, "Power System Harmonic"Jhon Wiley \& Sons, Ltd, New Zealand.

Aysen Arsoy, S. Mark Halpin, Yilu Liu, Paulo F. Ribeiro., 1999, "Modeling and Simulation of Power Sistem Harmonics", IEEE

Chen Bo, Zeng Xiangjun, Xv Yao., 2006, “ Three Tuned Passive Filter to Improve Power Quality", International Confrence on Power Sistem Technology. IEEE, 1-42440111-9/06, pp: 1-5.

Das, J.C., 2002, "Power System Analisis", Marcel Dekker, Inc, New York.

IEEE Std 519-1992., 1993, “IEEE

Recommended Practices and Requirements for Harmonic Control in Electric Power Sistems", New York.
Paice, Derek. A., 1996, "Power Electronic Converter Harmonic", IEEE Press, New York.

Roger C. Dugan, Mark F. McGranaghan, Surya Santoso, H. Wayne Beaty., 2004, "Electrical Power Sistem Quality, Second Edition", McGraw-Hill.

S.N. AL. Yousif, M. Z. C. Wanik, A. Mohamed., 2004, "Implementation of Different Passive Filter Designs for Harmonic Mitigation", National Power \& Energy Conference (PECon) Proceedings, 0-7803X724-41041320.00 02004 IEEE, pp: 229 - 234, Kuala Lumpur, Malaysia

Timothy L. Skvarenina., 2002, "The Power Electronics Handbook", CRC Press, New York 
